\title{
Studi Lama Waktu Tinggal Partikel di Kawasan Perairan Nusa Penida, Bali
}

\author{
Ida Bagus Andika Putra Anomª I Gede Hendrawan* a, I Dewa Nyoman Nurweda Putra ${ }^{a}$ \\ ${ }^{a}$ Program Studi Ilmu Kelautan, Fakultas Kelautan dan Perikanan, Universitas Udayana, Bali, Indonesia \\ *Corresponding author, email: gede.hendrawan@unud.ac.id
}

\section{ARTICLE INFO}

\section{ABSTRACT}

\section{Article history:}

Received: October $17^{\text {th }} 2019$

Received in revised form: May $19^{\text {th }} 2020$

Accepted: June $17^{\text {th }} 2020$

Available online: August $31^{\text {th }} 2020$
Keywords:

Residence Time

Particle

Nusa Penida

FVCOM

Simulation

\begin{abstract}
Nusa Penida is a tourist destination, located on the east of Bali, which is well-known of its natural panoramic. Increasing tourism sector in Nusa Penida may have positive impacts, but it can also have negative impacts, such as an increase in the amount of waste and other pollutants, which will eventually be discharged into the waters. High concentration of pollutant can reduce water quality. The water quality in the sea can be control by the residence time, and the sea current would spread waste in the ocean. Based on these problems, it is important to conduct a research on the movement and length of particle residence in the waters of Nusa Penida, Bali. This research was carried out in January 2019, to represent the rainy season conditions, and in July 2019, to represent the dry season conditions. The residence time was calculated using a numerical modeling method namely Finite Volume Coastal Ocean Model (FVCOM). Based on the simulation results, the residence time of particle in the dry and rainy season has a similar pattern. Areas with fast residence times are found in the eastern Nusa Penida waters, while areas with weak residence times are found in the Toyapakeh strait. Generally, Nusa Penida waters have a relatively short residence time, 1 - 4 hours
\end{abstract}

2020 JMRT. All right reserved.

\section{Pendahuluan}

Nusa Penida merupakan salah satu destinasi wisata di Pulau Bali yang sudah terkenal hingga ke mancanegara karena keindahan alam dan bawah lautnya. Nusa Penida merupakan salah satu pulau kecil yang menyimpan daya tarik wisata dan menjadi salah satu wilayah dengan kunjungan wisatawan yang paling banyak di Kabupaten Klungkung. Jumlah wisatawan yang berkunjung ke Nusa Penida pada tahun 2017 mencapai 292.734 jiwa (Badan Pusat Statistik Kabupaten Klungkung, 2018). Meningkatnya sektor pariwisata di Nusa Penida tak hanya dapat memberikan dampak yang positif bagi Nusa Penida, namun juga dapat memberikan dampak yang negatif. Tingginya aktifitas manusia juga dapat menimbulkan permasalahan yang dapat menyebabkan gangguan hingga bisa berdampak langsung terhadap ekosistem pesisir. Peningkatan aktifitas di pesisir Nusa Pendia dapat menyebabkan meningkatnya jumlah polutan dan pada akhirnya akan mencemari lingkungan. Semakin tinggi bahan pencemar maka dapat mengurangi kualitas perairan di Nusa Penida.

Kualitas perairan merupakan salah satu parameter yang digunakan dalam menentukan tingkat kesehatan lingkungan suatu ekosistem di pesisir (Guan, 2009). Wang (2014) mengatakan semakin tinggi aktifitas manusia maka dapat menyebabkan penurunan kualitas perairan seperti, seperti halnya sampah yang masuk ke laut akan dapat terbawa oleh arus laut dan mencemari wilayah perairan lainnya (Sala et al., 2009). Salah satu parameter yang sering digunakan untuk menunjukkan perubahan kondisi kualitas air suatu perairan adalah Residence time (Changbo et al.,
2017). Residence time atau yang sering disebut dengan lama waktu tinggal dapat menunjukkan lama waktu suatu partikel terdiam disuatu perairan hingga kemudian bergerak ke perairan lainnya (Liu et al., 2011; Li and Yao, 2015; Shen et al., 2011).

Penelitian mengenai lama waktu tinggal telah cukup banyak dilakukan secara global (Carlson et al., 2017; Du and Shen. 2016; Patgaonkar et al., 2012; Safak et al., 2015). Menurut Zhang dan Wang (2012) lama waktu tinggal partikel memiliki karakteristik yang berbeda-beda di setiap perairan. Lama waktu tinggal suatu partikel sangat dipengaruhi oleh adanya proses hidrodinamika, meteorology, geomorfologi, karakteristik dan posisi pelepasan partikel (Pham et al., 2014; Politikos et al., 2019) serta berhubungan erat dengan arus residu (Hendrawan dan Asai, 2014). Pola pergerakan dan lama waktu tinggal suatu partikel dapat diketahui dengan menggunakan beberapa metode yaitu observasi secara langsung di lapangan ataupun pemodelan numerik hidrodinamika (Huang et al., 2008). Metode observasi langsung memerlukan tenaga, waktu dan biaya yang sangat besar. Pemodelan numerik hidrodinamika merupakan salah satu metode yang dapat digunakan untuk memprediksi pergerakan partikel (Chen et al., 2011; Lebreton et al., 2012). Metode pemodelan numerik hidrodinamika telah banyak dikembangkan oleh berbagai pihak, salah satunya adalah Finite Volume Coastal Ocean Model (FVCOM) yang dikembangkan oleh Chen et al. (2006). Sementara itu, untuk mengetahui pergerakan partikel dilakukan dengan menggunakan metode Lagrange. Metode ini digunakan untuk melakukan penelusuran atau tracking partikel yang bergerak di perairan laut (Lebreton et al., 2012; Adhibusana, 2016). 
Penelitian mengenai pola pergerakan dan lama waktu tinggal partikel masih belum banyak ditemukan di perairan Nusa Penida, khususnya terkait kawasan konservasi perairan (KKP) Nusa Pendia. Untuk meningkatkan program pengelolaan KKP Nusa Penida, maka kajian waktu tinggal partikel akan dapat mendukung pengelolaan yang lebih baik di masa yang akan datang. Penelitian ini memanfaatkan keuntungan simulasi numerik FVCOM untuk melakukan analisis hidrodinamika kawasan Nusa Penida, dan metode Lagrange untuk menghitung waktu tinggal

\section{Metode}

\subsection{Lokasi Penelitian}

Perairan Nusa Penida terletak di wilayah kecamatan Nusa Penida dan masuk kedalam wilayah administrasi Kabupaten Klungkung, Bali. Simulasi model dilakukan pada bulan Januari untuk mewakili kondisi musim barat dan bulan Juli untuk mewakili kondisi musim timur pada tahun 2019. Pengambilan data insitu berupa data kecepatan arus, arah arus, pergerakan dan waktu tinggal partikel yang digunakan sebagai validasi data model dilakukan pada bulan Januari 2019. Lokasi pengambilan data lapangan dilakukan di perairan Nusa Penida seperti pada gambar 1.

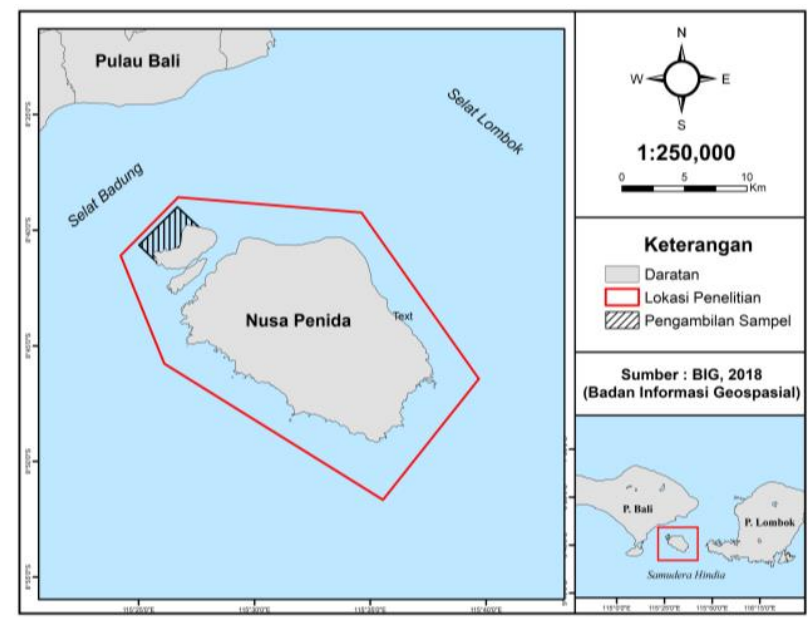

Gambar 1. Peta Lokasi Penelitian

\subsection{Desain Model}

Perhitungan numerik dilakukan selama 31 hari menggunakan 10 sigma Layer. Komponen elevasi pasang surut yang digunakan untuk model berjumlah 4 komponen yaitu S2, M2, K1, dan O1 yang dihitung dengan model ORI-Tide (Ocean Research Institute tide model) (Matsumoto et al., 1995). Data batimetri bersumber dari Dinas Hidro Oseanografi (Dishidros) TNI AL tahun 2015. Data kecepatan dan arah angin tahun 2009-2018 bersumber dari European Centre for Medium-Range Weather Forecasts (ECMWF) dengan resolusi sebesar 0.125 derajat. Data suhu dan salinitas perairan Nusa Penida didapatkan dari World Ocean Atlas berupa data klimatologi musim barat dan musim timur selama 10 tahun dari tahun 2009 sampai 2018 dengan resolusi sebesar 1 derajat. Grid yang digunakan dalam model adalah unstructural triangular grid dengan resolusi $100 \mathrm{~m}$ untuk bagian coastline Nusa Penida, $500 \mathrm{~m}$ untuk bagian coastline Bali dan Lombok, serta $1000 \mathrm{~m}$ untuk daerah open boundary (batas terbuka). Partikel yang dimaksud pada penelitian ini adalah partikel yang memiliki netral buoyancy yaitu partikel tersebut dominan mengikuti pergerakan massa air (Chen et al., 2006). Domain model dapat dilihat pada Gambar 2.

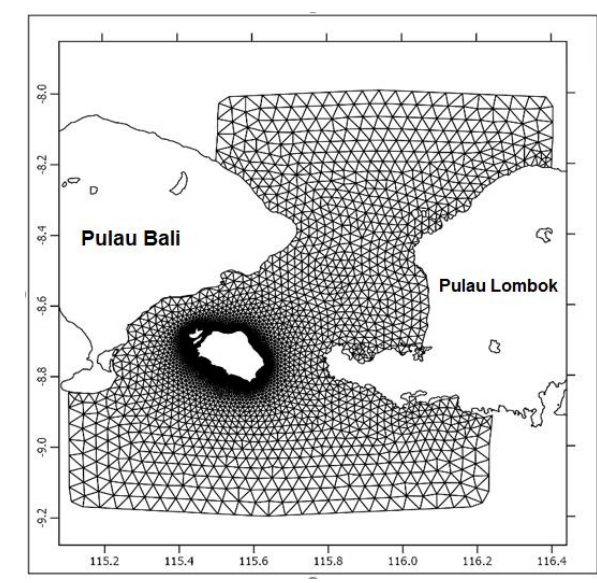

Gambar 2. Domain Model dengan unstructured triangular grid

\subsection{Model Hidrodinamika}

Persamaan hidrostatis tiga dimensi (3D) yang terdapat dalam FVCOM terdiri dari persamaan kontinuitas (1), momentum (2-4), suhu (5), salinitas (6), densitas (7), dan elevasi pasang surut (8) (Chen et al., 2006):

$\frac{\partial \zeta}{\partial t}+\frac{\partial D u}{\partial x}+\frac{\partial D v}{\partial y}+\frac{\partial \omega}{\partial \sigma}=0$

$\frac{\partial u D}{\partial t}+\frac{\partial u^{2} D}{\partial x}+\frac{\partial u v D}{\partial y}+\frac{\partial u \omega}{\partial \sigma}-f v D=-g D \frac{\partial \zeta}{\partial x}-$

$\frac{g D}{\rho_{0}}\left[\frac{\partial}{\partial x}\left(D \int_{\sigma}^{0} \rho d \sigma^{\prime}\right)+\partial \rho \frac{\partial D}{\partial x}\right]+\frac{1}{D} \frac{\partial}{\partial \sigma}\left(K_{m} \frac{\partial u}{\partial \sigma}\right)$

$+D F_{x}$

$\frac{\partial v D}{\partial t}+\frac{\partial v^{2} D}{\partial x}+\frac{\partial u v D}{\partial y}+\frac{\partial v \omega}{\partial \sigma}-f u D=-g D \frac{\partial \zeta}{\partial y}-$

$\frac{g D}{\rho_{0}}\left[\frac{\partial}{\partial y}\left(D \int_{\sigma}^{0} \rho d \sigma^{\prime}\right)+\partial \rho \frac{\partial D}{\partial y}\right]+\frac{1}{D} \frac{\partial}{\partial \sigma}\left(K_{m} \frac{\partial v}{\partial \sigma}\right)$

$+D F_{y}$

$\frac{\partial w D}{\partial t}+\frac{\partial u w D}{\partial x}+\frac{\partial v w D}{\partial y}+\frac{\partial w \omega}{\partial \sigma}=-\frac{1}{\rho_{o}} \frac{\partial q}{\partial \sigma}+$ $\frac{\partial}{\partial \sigma}\left(\frac{K_{m}}{D} \frac{\partial w}{\partial \sigma}\right)+D F_{w}$

$$
\begin{aligned}
& \frac{\partial T D}{\partial t}+\frac{\partial T u D}{\partial x}+\frac{\partial T \nu D}{\partial y}+\frac{\partial T \omega}{\partial \sigma}=\frac{1}{D} \frac{\partial}{\partial \sigma}\left(K_{h} \frac{\partial T}{\partial \sigma}\right) \\
& +D H+D F_{T}
\end{aligned}
$$

$\frac{\partial S D}{\partial t}+\frac{\partial S u D}{\partial x}+\frac{\partial S v D}{\partial y}+\frac{\partial S \omega}{\partial \sigma}=\frac{1}{D} \frac{\partial}{\partial \sigma}\left(K_{h} \frac{\partial S}{\partial \sigma}\right)$

$+D F_{S}$

$\rho=\rho(T, S)$

$\zeta_{0}=\bar{\zeta}_{0}+\sum_{i=1}^{N_{0}} \zeta_{i} \cos \left(\omega_{i} t-\theta_{i}\right)$

dimana $\mathrm{x}$ adalah arah untuk timur dan barat, $\mathrm{y}$ adalah arah untuk utara dan selatan, dan $\sigma$ adalah arah vertikal dalam sistem koordinat kartesian; $\mathrm{u}, \mathrm{v}$, dan $\omega$ adalah komponen kecepatan arus 
$(\mathrm{m} / \mathrm{s})$ untuk arah $\mathrm{x}, \mathrm{y}, \sigma ; \mathrm{T}$ adalah suhu $\left({ }^{\circ} \mathrm{C}\right) ; \mathrm{S}$ adalah salinitas (ppt); $\rho$ adalah denistas akhir $\left(\mathrm{kg} / \mathrm{m}^{2}\right)$ sedangkan $\rho_{0}$ adalah densitas awal $\left(\mathrm{kg} / \mathrm{m}^{2}\right)$; $\mathrm{f}$ adalah gaya coriolis $\left({ }^{\circ}\right)$; $\mathrm{g}$ adalah gravitasi $(\mathrm{m} / \mathrm{s}) ; \mathrm{K}_{\mathrm{m}}$ adalah vertical eddy viscosity $\left(\mathrm{m}^{2} / \mathrm{s}\right)$; dan $\mathrm{K}_{\mathrm{h}}$ adalah thermal vertical eddy diffusion coefficient $\left(\mathrm{m}^{2} / \mathrm{s}\right) . \mathrm{F}_{\mathrm{X}}, \mathrm{F}_{\mathrm{Y}}$, $\mathrm{F}_{\mathrm{T}}$, dan $\mathrm{F}_{\mathrm{S}}$ merepresentasikan dari gesekan arah $\mathrm{x}$ dan $\mathrm{y}$, thermal, dan difusi salinitas (N); D adalah total kedalaman kolom perairan (m); $\mathrm{H}$ adalah penyerapan radiasi ke kolom perairan; $\zeta$ adalah tinggi elevasi permukaan perairan (m); $\zeta_{i}, \omega_{i}, \theta_{i}$ merepresentasikan amplitudo (m), frekuensi (s), dan phase dari pasang surut $\left({ }^{\circ}\right)$; t adalah waktu (s).

\subsection{Model 2D-Lagrangian Particle Tracking}

Metode Lagrange banyak digunakan untuk melakukan penelusuran partikel yang mengambang pada perairan laut. Partikel yang disimulasikan pada model ini digerakkan berdasarkan model arus yang telah dilakukan sebelumnya serta diasumsikan memiliki densitas dan ukuran yang sama. Persamaan yang digunakan dalam Model Lagrangian adalah sebagai berikut (Chen et al., 2006):

$$
\begin{aligned}
& x_{n+1}=x_{n}+\Delta t\left[\frac{u\left(\xi_{1}, \eta_{1}\right)}{6}+\frac{u\left(\xi_{2}, \eta_{2}\right)}{3}+\frac{u\left(\xi_{3}, \eta_{3}\right)}{3}+\frac{u\left(\xi_{4}, \eta_{4}\right)}{6}\right] \\
& y_{n+1}=y_{n}+\Delta t\left[\frac{v\left(\xi_{1}, \eta_{1}\right)}{6}+\frac{v\left(\xi_{2}, \eta_{2}\right)}{3}+\frac{v\left(\xi_{3}, \eta_{3}\right)}{3}+\frac{v\left(\xi_{4}, \eta_{4}\right)}{6}\right]
\end{aligned}
$$

dimana $\mathrm{x}$ dan $\mathrm{y}$ merupakan posisi partikel pada saat waktu $\mathrm{t}, \mathrm{u}$ dan $\mathrm{v}$ adalah medan kecepatan serta $\Delta \mathrm{t}$ adalah langkah waktu.

\subsection{Analisis Data}

Analisis pergerakan dan lama waktu tinggal partikel dibagi menjadi beberapa daerah analisis. Pembagian wilayah pada penelitian ini ditunjukkan pada gambar 3. Daerah yang dianalisis dibagi menjadi 5 daerah yaitu daerah $\mathrm{N} 1$ merupakan daerah tengah perairan Nusa Penida berdasarkan zona wilayah KKP, daerah N2 merupakan daerah utara perairan Nusa Penida, daerah N3 merupakan daerah timur perairan Nusa Penida, daerah N4 merupakan daerah selatan perairan Nusa Penida dan daerah N5 merupakan daerah barat perairan Nusa Penida,

Analisis pergerakan partikel dilakukan dengan menghitung persentase posisi akhir partikel berdasarkan daerah pelepasan partikelnya. Partikel tersebut kemudian diklasifikasikan berdasarkan daerah asal partikel pertama kali dilepaskan, kemudian dihitung jumlah posisi akhir partikel setelah 30 hari simulasi diseluruh daerah pelepasan partikel. Analisis dilakukan dalam rentang waktu satu bulan dengan waktu perhitungan persentase partikel setiap minggu. Hal ini dilakukan agar pergerakan partikel terlihat lebih jelas.

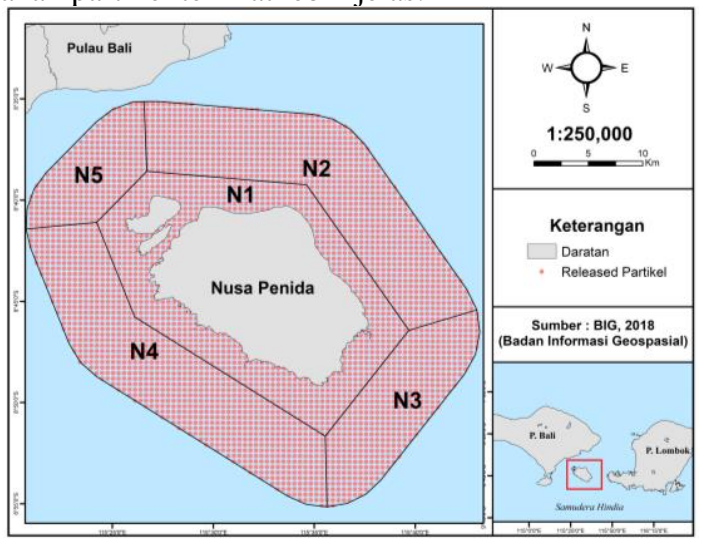

Gambar 3. Lokasi Pelepasan Partikel N1-N5 dan Pembagian Daerah Analisis
Analisis waktu tinggal partikel dapat diketahui dengan melihat seberapa lama partikel berada dalam suatu area tertentu berdasarkan pergerakan dari partikel tersebut. Pada penelitian ini, metode batas kotak dengan resolusi grid 500 x 500 m digunakan untuk mencari lama waktu tinggal dari partikel sesuai dengan jarak pelepasan setiap partikel (Bilgili et al., 2005; Hendrawan dan Asai, 2014). Partikel tersebut kemudian dilepaskan masingmasing sebanyak 24 kali pada musim barat dan musim timur dengan interval waktu setiap jam dengan tujuan untuk mewakili disetiap kondisi pasang surut. Seluruh hasil waktu tinggal partikel tersebut dirata-rata untuk mendapatkan hasil lama waktu tinggal partikel yang mewakili semua kondisi pasang surut.

\subsection{Validasi Data}

Data yang divalidasi adalah elevasi pasang surut, arus dan pergerakan partikel. Data arus dan pergerakan partikel dari hasil model divalidasi dengan data pengukuran insitu yang diambil selama 12 jam menggunakan drifter pada tanggal 15 Februari 2019. Sementara data elevasi pasang surut divalidasi menggunakan data pengamatan observasi yang didapatkan dari Dinas Hidro-Oceanografi TNI AL (DISHIDROS) sebanyak 3 titik pengamatan.

Validasi hasil model dengan observasi dilakukan dengan cara menghitung korelasi (r) untuk mengetahui hubungan dan kesamaan pola antar kedua data yang dibandingkan. Formula untuk menghitung korelasi ditulis pada persamaan (11) (Sugiono, 2012). Sementara perhitungan Root Mean Square Error (RMSE) dilakukan untuk dapat mengetahui nilai error dari hasil model dengan data observasi yang ditulis pada persmaan (12) (Soliwoda, 2014).

$$
\begin{aligned}
& r=\frac{\sum x y-\frac{\left(\sum x\right)\left(\sum y\right)}{n}}{\sqrt{\left(\sum x^{2}-\frac{\left(\sum x\right)^{2}}{n}\right)\left(\sum y^{2}-\frac{\left(\sum y\right)^{2}}{n}\right)}} \\
& R M S E=\sqrt{\frac{E_{i=1}^{i}(x-y)^{2}}{n}}
\end{aligned}
$$

Dimana $\mathrm{r}$ adalah koefisien korelasi; RMSE adalah niliai error $\mathrm{x}$ adalah data model; $\mathrm{y}$ adalah data observasi; $\sum \mathrm{xy}$ adalah jumlah antara data model dan data observasi; $\sum \mathrm{x}$ jumlah data model; $\sum \mathrm{y}$ jumlah data observasi; $n$ adalah jumlah data.

\section{Hasil dan Pembahasan}

\subsection{Validasi Data}

Untuk menunjukan validitas data hasil perhitungan model, dilakukan perbandingan dengan data hasil observasi. Data yang divalidasi adalah data elevasi pasang surut, komponen arah arus dan kecepatan arus serta pergerakan partikel. Validasi elevasi pasang surut dari hasil model dan observasi didapatkan berdasarkan dari empat komponen pasang surut yaitu komponen semidiurnal utama (M2, S2) dan komponen diurnal (K1, O1) yang dibandingkan selama 720 jam. Elevasi pasang surut hasil observasi yang dihitung sesuai dengan data pengamatan yang disediakan oleh DISIHDROS sebanyak 3 daerah stasiun pengamatan, yaitu Benoa, Lembar dan Ampenan. Pola elevasi pasang surut hasil model dan observasi pada 3 stasiun pengamatan tersebut dapat dilihat pada gambar 4 . 


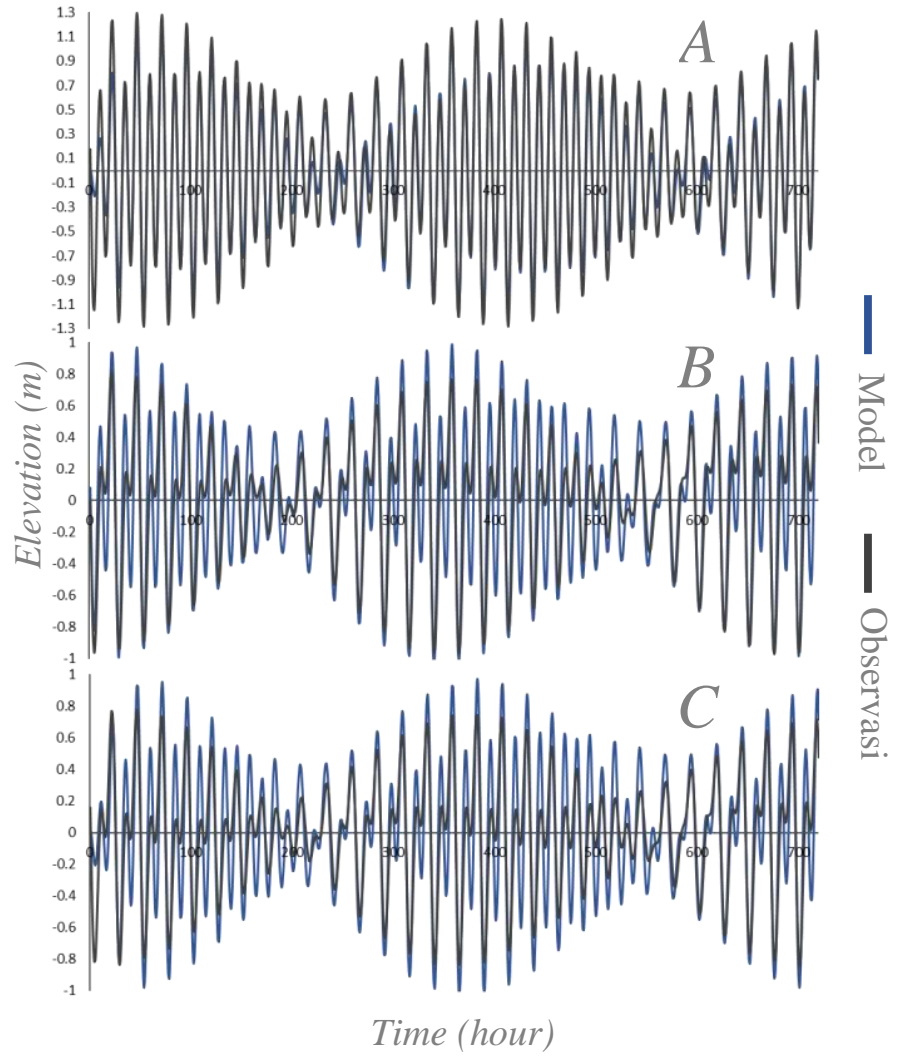

Gambar 4. Perbandingan Elevasi Pasang Surut Hasil Model dan Observasi pada Stasiun Benoa (A), Lembar (B), dan Ampenan (C)

Secara umum, elevasi pasang surut antara hasil perhitungan model dan observasi telah memiliki pola yang serupa pada seluruh stasiun pengamatan yaitu Benoa, Lembar dan Ampenan dengan nilai korelasi masing-masing sebesar 0.98, 0.84, dan 0.86 . Hal tersebut menandakan bahwa antara hasil simulasi dengan observasi memiliki hubungan sangat kuat pada setiap stasiunnya, serta menghasilkan nilai RMSE masing-masing sebesar $0.14 \mathrm{~m}$, 0.24 m, dan 0.22 m untuk Benoa, Lembar dan Ampenan berturutturut. Berdasarkan hal tersebut dapat dikatakan bahwa kondisi elevasi pasang surut hasil simulasi dapat merepresentasikan kondisi pasang surut di perairan Nusa Penida khususnya dan perairan Selat Lombok secara umum.

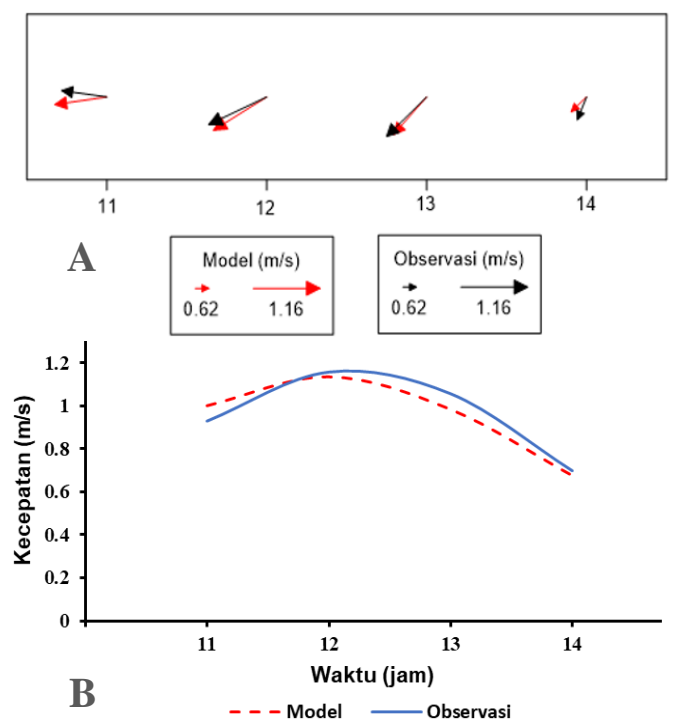

Gambar 5. Perbandingan Komponen Arah Arus (A) dan Kecepatan Arus (B) Hasil Model dan Observasi

Validasi pergerakan arus dari hasil simulasi dibandingkan dengan data hasil observasi yang telah dilakukan pada 15 Februari 2019. Komponen arus yang divalidasi adalah arah arus dan kecepatan arus. Hasil validasi arus antara data simulasi dan observasi untuk arah dan kecepatan arus dapat dilihat pada gambar 5. Secara umum pola pergerakan arus antara hasil simulasi dan observasi telah memiliki pola yang serupa, sama hal nya dengan pola kecepatan arus. Kecepatan arus antara hasil simulasi dengan observasi menghasilkan nilai korelasi sebesar 0.95 dengan RMSE $0.003 \mathrm{~m} / \mathrm{s}$. Hal tersebut menandakan bahwa antara hasil simulasi dengan observasi memiliki hubungan yang sangat kuat. Berdarkan hal tersebut, dapat dikatakan bahwa secara umum pergerakan arus hasil simulasi sudah dapat merepresentasikan kondisi yang sesuai dengan kondisi arus di perairan Nusa Penida.

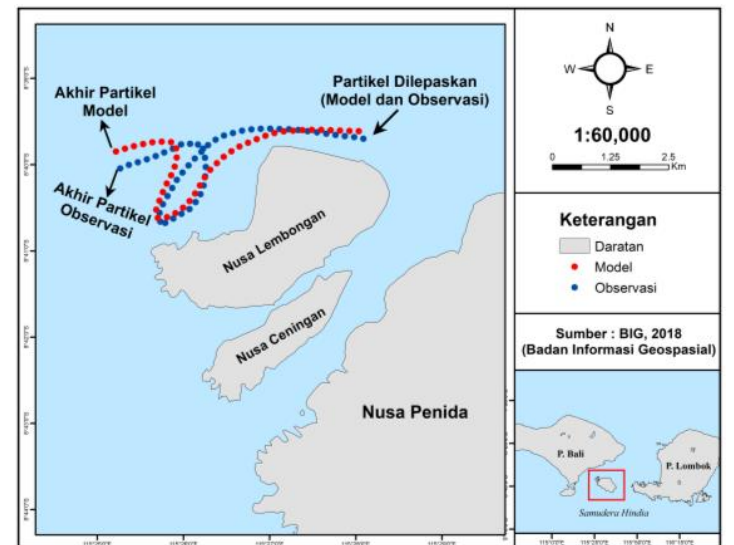

Gambar 6. Perbandingan Pergerakan Partikel Hasil Model dan Observasi

Validasi pergerakan partikel dari hasil simulasi dibandingkan dengan pergerakan partikel hasil observasi dilapangan yang dilakukan pada tanggal 15 Februari 2019. Perbandingan pergerakan partikel hasil simulasi dengan pergerakan partikel hasil observasi dapat dilihat pada gambar 6. Hasil validasi pergerakan partikel dari simulasi telah menunjukkan pola pergerakan yang serupa dengan pergerakan partikel hasil observasi. Selisih jarak pergerakan partikel pada posisi akhir partikel hasil simulasi dengan observasi menunjukkan perbedaan nilai sebesar $432,63 \mathrm{~m}$. Secara umum, pergerakan partikel hasil simulasi sudah dapat merepresentasikan pergerakan partikel di lapangan. Berdasarkan hal tersebut, hasil simulasi sudah dapat digunakan untuk menggambarkan pola pergerakan partikel dikawasan perairan Nusa Penida, Bali.

\subsection{Pergerakan Partikel di Perairan Nusa Penida}

Pergerakan partikel didapatkan dari hasil perpindahan partikel tersebut setelah 30 hari berdasarkan pembagian daerah masing-masing yang dibagi menjadi 5 daerah. Pergerakan partikel pada musim barat dapat dilihat pada gambar 7 . 


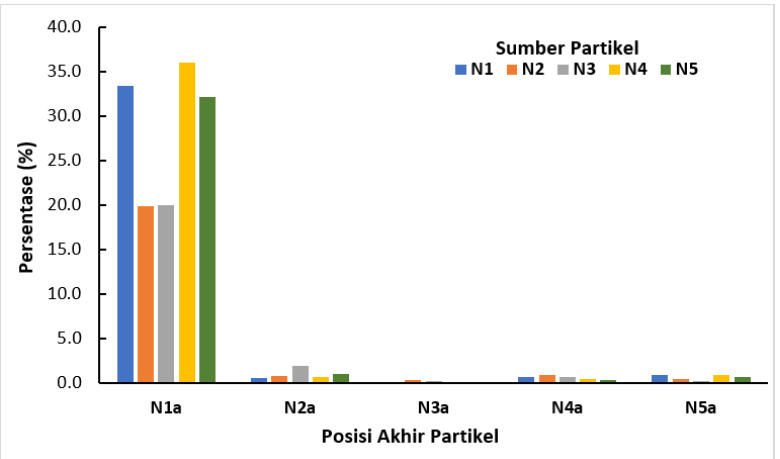

Gambar 7. Pergerakan Partikel di Perairan Nusa Penida pada Musim Barat

Hasil simulasi pergerakan partikel saat musim barat menunjukkan bahwa sebagian besar partikel yang dilepaskan setelah 30 hari simulasi bergerak menuju ke luar wilayah analisis N1-N5, namun masih berada didaerah domain model. Partikel yang bergerak menuju keluar wilayah analisis memiliki kisaran yang cukup besar, yakni sebanyak $64-77 \%$ partikel yang dilepaskan (N1-N5). Selain itu, partikel yang masih berada di wilayah analisis sebagian besar berada di daerah N1 dengan kisaran sebanyak 20-36\% partikel. Sama halnya dengan pergerakan partikel saat musim timur, juga menunjukkan sebagian besar partikel yang dilepaskan setelah 30 hari simulasi bergerak menuju ke luar wilayah analisis yaitu N1-N5, namun masih berada didaerah domain model. Partikel yang bergerak menuju keluar wilayah analisis memiliki kisaran yang lebih besar dibandingkan dengan kondisi saat musim barat, yakni sebanyak 86-99\% partikel yang dilepaskan (N1-N5). Selain itu, partikel yang masih berada di wilayah analisis sebagian besar berada di daerah $\mathrm{N} 1$ dengan kisaran sebanyak 1-13\% partikel.

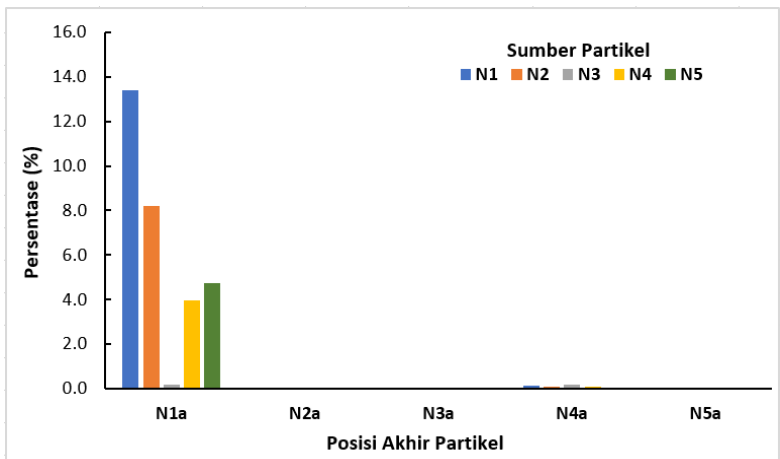

Gambar 8. Pergerakan Partikel di Perairan Nusa Penida pada Musim Timur

Secara umum, dapat dilihat bahwa persentase posisi akhir partikel terbesar setelah 30 hari simulasi pada musim barat dan musim timur berada pada daerah N1. Rata-rata sebesar $28.51 \%$ partikel untuk musim barat dan $6.93 \%$ partikel untuk musim timur berada pada daerah $\mathrm{N} 1$, sedangkan $71.49 \%$ partikel dari musim barat dan $93.07 \%$ partikel dari musim timur berada diluar wilayah analisis. Daerah N1 merupakan daerah yang berada disekitar Kawasan Konservasi Perairan Nusa Penida (KKP) yang dekat dengan daerah pesisir. Berdasarkan hal tersebut, dapat dikatakan sebagian besar partikel yang dilepaskan cenderung bergerak menuju ke pesisir perairan pulau Nusa Penida pada daerah N1. Jika partikel tersebut diasumsikan sebagai polutan seperti sampah yang mengapung, maka hal tersebut dapat memberikan dampak yang tidak baik bagi organisme hingga eksosistem di daerah tersebut. Partikel yang jika diasumsikan sebagai sampah yang mengapung tersebut dapat termakan oleh organisme laut di wilayah KKP Nusa Penida, dan atau dapat terdampar di wilayah pantai.

Pergerakan partikel diperairan Nusa Penida selama 30 hari simulasi cenderung lebih besar berada diluar wilayah analisis. Hasil ini dapat memberikan arti bahwa wilayah KKP Nusa Penida merupakan wilayah perlintasan partikel, baik jika sumber partikel berada di dalam wilayah KKP ataupun dari luar wilayah KKP. Meskipun demikian, sebagian partikel akan memberikan dampak bagi ekosistem di kawasan KKP Nusa Penida. Tingginya persentase posisi akhir partikel yang berada diluar wilayah analisis pada musim timur dapat disebabkan karena pergerakan arus cenderung dominan bergerak dari arah utara menuju ke selatan dengan rata-rata kecepatan arus yang lebih besar dibandingkan dengan kecepatan arus pada musim barat, sehingga partikel yang dilepaskan akan melewati wilayah analisis setelah 30 hari simulasi.

\subsection{Pola Waktu Tinggal Partikel di Perairan Nusa Penida}

Waktu tinggal partikel dapat diketahui dengan melihat seberapa lama partikel berada dalam suatu area tertentu. Metode batas kotak dengan resolusi grid 500m x 500m digunakan untuk mengetahui lama waktu tinggal partikel di perairan Nusa Penida. Analisis lama waktu tinggal partikel didapatkan berdasarkan hasil rata-rata lama waktu tinggal partikel yang telah dilepaskan masing-masing sebanyak 24 kali pada musim barat dan musim timur dengan interval waktu setiap jam. Hal tersebut bertujuan agar waktu tinggal partikel dapat mewakili seluruh kondisi pasang surut. Hasil waktu tinggal partikel saat musim barat dapat dilihat pada gambar 9. Daerah dengan waktu tinggal yang singkat ditandakan dengan daerah berwarna merah, sedangkan waktu tinggal yang lebih lama ditandakan dengan daerah berwarna biru.

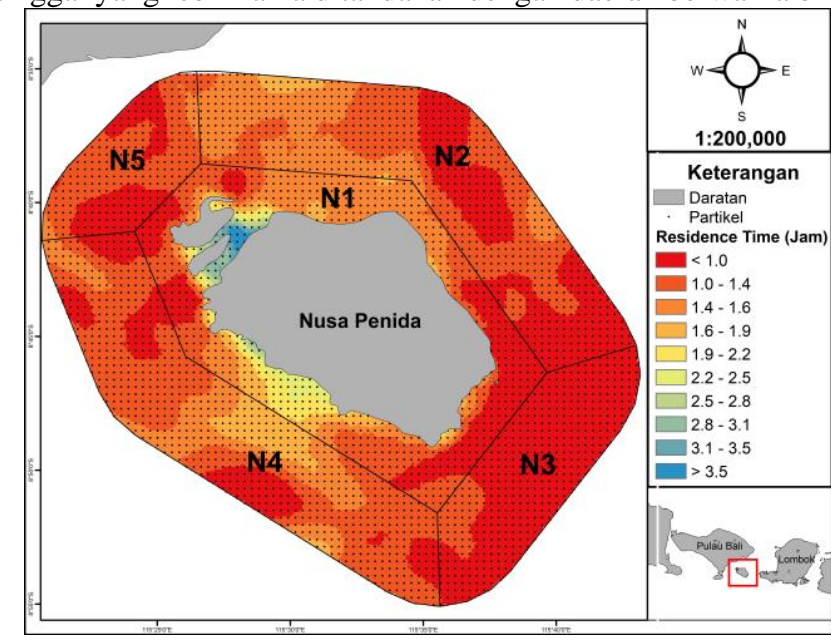

Gambar 9. Pola Lama Waktu Tinggal Partikel pada Musim Barat

Waktu tinggal partikel saat musim barat memiliki rata-rata waktu tinggal yang relative singkat, dengan waktu tinggal berkisar antara 1 jam hingga 4 jam. Daerah dengan waktu tinggal partikel yang singkat terdapat pada daerah N3 berkisar kurang lebih 1 jam, daerah tersebut merupakan perairan timur Nusa Penida berbatasan dengan pulau Lombok. Hal itu sesuai dengan karakteristik perairan tersebut, dimana perairan tersebut memiliki pergerakan arus yang tinggi dibandingkan dengan perairan lainnya (Hendrawan and Asai, 2011). Waktu tinggal partikel yang lama cenderung terdapat pada perairan antara pulau Nusa Lembongan dengan pulau Nusa Penida, yaitu selat Toyapakeh. Perairan tersebut memiliki waktu tinggal yang berkisar hingga lebih dari 4 jam. Selain itu, daerah dengan waktu tinggal yang relative cukup lama juga terdapat pada perairan selatan Nusa 
Penida. Perairan tersebut memiliki waktu tinggal yang berkisar antara 2 hingga 3 jam.

Waktu tinggal partikel saat musim timur memiliki pola yang tak jauh berbeda dengan waktu tinggal saat musim barat. Waktu tinggal partikel saat musim timur dapat dilihat pada gambar 10 . Waktu tinggal yang lebih lama terdapat pada daerah perairan antara pulau Nusa Lembongan dengan pulau Nusa Penida, yaitu selat Toyapakeh. Perairan tersebut memiliki waktu tinggal yang berkisar hingga lebih dari 4 jam. Selain itu, daerah dengan waktu tinggal yang relative cukup lama juga terdapat pada perairan selatan Nusa Penida serta perairan utara Nusa Penida dengan waktu tinggal yang berkisar antara 2 hingga 3 jam. Daerah dengan waktu tinggal partikel yang singkat terdapat pada daerah N3 berkisar kurang lebih 1 jam, yang mana daerah tersebut merupakan perairan timur Nusa Penida berbatasan dengan pulau Lombok.

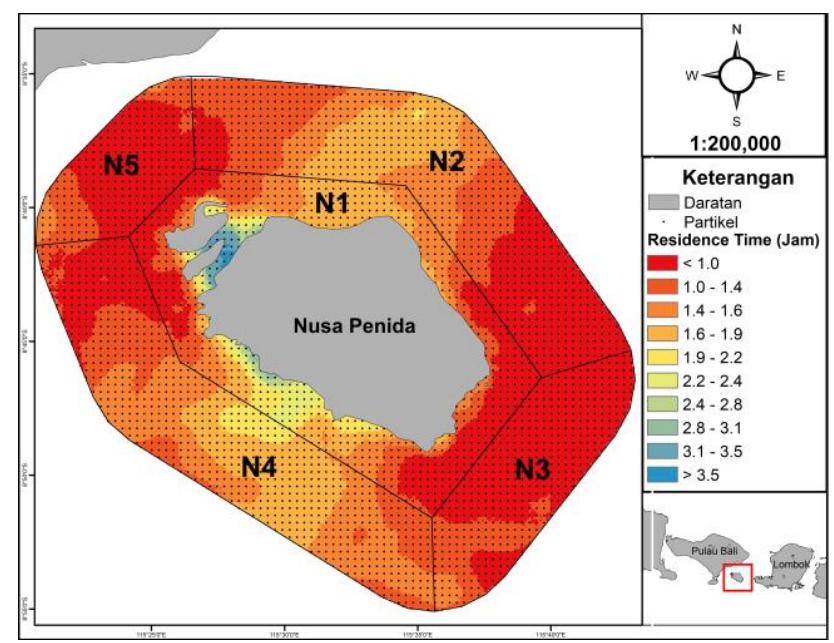

Gambar 10. Pola Lama Waktu Tinggal Partikel pada Musim Timur

Berdasarkan hal tersebut, dapat dikatakan bahwa lama waktu tinggal partikel sangat berkaitan erat dengan adanya pergerakan arus. Hal tersebut dikarenakan partikel mengikuti dan digerakkan oleh arus. Waktu tinggal partikel pada musim barat dan musim timur memiliki pola waktu tinggal yang tak jauh berbeda dengan kisaran rentang waktu sebesar 1 jam hingga 4 jam. Secara umum, daerah dengan lama waktu tinggal yang singkat pada kedua musim terdapat pada daerah sekitar N3 yaitu perairan Nusa Penida bagian timur. Selain itu, perairan selat Badung juga memiliki rata-rata waktu tinggal yang relative singkat. Hal tersebut dapat disebabkan karena perairan timur Nusa Penida dan perairan Selat Badung merupakan jalur utama pergerakan arus di Selat Lombok, sehingga kedua perairan tersebut memiliki kecepatan arus yang cukup tinggi dibandingkan dengan perairan lainnya (Hendrawan dan Asai, 2011).

Waktu tinggal partikel yang singkat didaerah perairan Nusa Penida bagian timur juga disebabkan karena tingginya kecepatan arus didaerah tersebut dimana menurut Purba dan Utami (2006) bahwa tingginya kecepatan arus di perairan antara Nusa Penida dengan Lombok dikarenakan adanya penyempitan serta perubahan kedalaman yang ekstrim pada daerah tersebut yang sering disebut dengan ambang (sill). Kecepatan arus di perairan Nusa Penida bagian timur berkisar sebesar $1.9 \mathrm{~m} / \mathrm{s}$ (Susanto et al., 2005). Hendrawan dan Asai (2011) juga mengatakan bahwa kecepatan arus pada daerah timur perairan Nusa Penida dapat mencapai hingga lebih dari $2 \mathrm{~m} / \mathrm{s}$.

Daerah dengan waktu tinggal partikel yang lama cenderung terdapat pada perairan selatan Nusa Penida dan perairan antara Nusa Lembongan dengan Nusa Penida yaitu Selat Toyapakeh. Akan tetapi, selat Toyapakeh cenderung memiliki kecepatan arus cukup tinggi namun memiliki waktu tinggal yang relative lama. Hal tersebut dapat disebabkan oleh adanya pengaruh pasang surut, daerah perairan yang sempit cenderung sangat dipengaruhi oleh pasang surut. Pasang surut tersebut dapat menyebabkan partikel yang dilepaskan cenderung lebih lama terdiam didaerah tersebut karena partikel dapat bergerak bolak balik di perairan tersebut.

Waktu tinggal partikel yang lama pada kedua musim cenderung terdapat di perairan utara dan perairan selatan pada daerah N1. Daerah tersebut merupakan perairan yang masuk ke dalam wilayah kawasan Konservasi Perairan, sehingga kawasan perairan Nusa Penida serta biota dan ekosistem laut yang terdapat di kawasan tersebut penting untuk dijaga secara berkelanjutan. Apabila diperairan tersebut terdapat polutan berbahaya dengan karakterstik perairan yang memiliki waktu tinggal yang lambat, maka hal tersebut dapat mempengaruhi organisme dan ekosistem disekitarnya. Perairan selatan Nusa Penida merupakan perairan dimana salah satu organisme khas Nusa Penida melakukan aktifitas mencari makan, yaitu pari manta (Germanov et al., 2018). Semakin lama partikel terdiam diperairan tersebut maka kemungkinan besar partikel (contohnya plastik) tersebut dapat termakan oleh biota laut, misalnya keberadaan hewan karismatik pari manta di perairan Nusa Penida, karena binatang tersebut merupakan binatang filter feeder, dimana binatang tersebut dapat menyaring hingga ratusan meter kubik air setiap harinya. Termakannya polutan tersebut dapat menimbulkan perubahan pada organisme, baik secara fisiologis ataupun secara anatomis (Tanaka et al., 2013).

\section{Simpulan}

Lama waktu tinggal partikel saat musim barat dan musim timur memiliki pola waktu tinggal yang tak jauh berbeda. Daerah dengan lama waktu tinggal yang singkat terdapat di wilayah perairan Nusa Penida bagian timur, sedangkan daerah dengan waktu tinggal yang lama terdapat di perairan selat Toyapakeh. Apabila diperairan tersebut terdapat polutan berbahaya dengan karakterstik perairan yang memiliki waktu tinggal yang lama, maka hal tersebut dapat memberikan dampak buruk bagi organisme dan ekosistem disekitarnya. Namun secara keseluruhan, perairan Nusa Penida memiliki waktu tinggal yang relative singkat, sehingga diharapkan dampak dari polutan yang melewati kawasan konservasi perairan Nusa Penida dapat diminamalisir

\section{Ucapan terimakasih}

Penulis mengucapkan terimakasih kepada Laboratorium Komputasi Fakultas Kelautan dan Perikanan Universitas Udayana yang telah memberikan fasilitas komputer untuk melakukan simulasi model.

\section{Daftar Pustaka}

Adhibusana MN. 2016. Studi Pola Arus Dan Pergerakan Partikel Di Kawasan Perairan Pesisir Barat Kabupaten Badung, Bali [skripsi]. Badung: Fakultas Kelautan dan Perikanan, Universitas Udayana. 113 hal.

Badan Pusat Statistik Kabupaten Klungkung. (2018). Klungkung Dalam Angka 2018. Badan Pusat Statistik Kabupaten Klungkung.

Bilgili A, et al. 2005. Estuary/Ocean Exchange and Tidal Mixing in Gulf of Maine estuary: A Langrangian Modeling Study, Estuarine. Coastal and Self science, 65: 607-624. https://doi.org/10.1016/j.ecss.2005.06.027 
Carlson,D.F.,Suaria, G.,Aliani,S.,Fredj,E.,Fortibuoni,T.,Griffa,A.,Russo, A.,Melli,V., 2017. Combining litter observations with a Regional Ocean model to identify sources and sinks of floating debris in a Semi-Enclosed Basin: the Adriatic Sea. Front. Mar. Sci. 4, 78. https://doi.org/10.3389/fmars.2017.00078

Changbo Jiang, Yizhuang Liu, Yuannan Long, Changshan Wu. 2017. Estimation of Residence Time and Transport Trajectory in Tieshangang Bay, China. Changsha University of Science \& Technology, China. Water 2017, 9, 321. https://doi.org/10.3390/w9050321

Chen C, et al. 2011. FVCOM model estimate of the location of Air France 447.Ocean dynamics. https://doi.org/10.1007/s10236-0120537-5.

Chen, C., Beardsley, R.C. and Cowles, G., 2006. An unstructured grid, finitevolume coastal ocean model-FVCOM user manual, 2nd edn. School for Marine Science and Technology, University of Massachusetts Dartmouth (p. 318). New Bedford. Technical report SMAST/UMASSD-06-0602.

Du, J., \& Shen, J. (2016). Water residence time in Chesapeake Bay for 1980-2012. Journal of Marine Systems, 164, 101-111. https://doi.org/10.1016/j.jmarsys.2016.08.011

Germanov ES, Marshall AD, et al. 2018. Microplastics: no small problem for filter-feeding megafauna. Trends in Ecology $\mathcal{E}$ Evolution. XX (YY) : 6 - 11. https://doi.org/10.1016/j.tree.2018.01.005

Guan X. 2009. Monitoring Lake Simcoe water quality using Landsat TM images [MS Thesis]. University of Waterloo: waterloo-Canada.

Hendrawan IG, Asai K. 2011. Numerical Study of Tidal Upwelling Over the Sill in The Lombok Strait (Indonesia). Di dalam: International Offshore and Polar Engineering Conference. Proceedings of the twenty-first (2011); 19-24 June 2011. Maui, Hawaii, USA. hlm 949-956.

Hendrawan, I.G. and Asai, K., 2014. Numerical study on tidal currents and seawater exchange in the Benoa Bay, Bali, Indonesia. Acta Oceanologica Sinica, 33(3), pp.90-100. https://doi.org/10.1007/s13131014-0434-5

Hendrawan, I.G., Uniluha, D. and Maharta, I.P.R.F., 2016. Karakteristik Total Padatan Tersuspensi (Total Suspended Solid) Dan Kekeruhan (Turbidity) Secara Vertikal Di Perairan Teluk Benoa, Bali. Journal of Marine and Aquatic Sciences, 2(1), pp.29-33.

Huang W, Liu X, Chen X. 2008. Numerical modeling of hydrodynamics and salinity transport In Little Manatee River. J Coast Res Spec Issue 52:13-24. https://doi.org/10.2112/1551-503652.sp1.13

Lebreton, et al. 2012. Numerical modeling of floating debris in the world oceans. Marine Pollution Bulletin. 64:653-661. https://doi.org/10.1016/j.marpolbul.2011.10.027

Li, Y., Yao, J., 2015. Estimation of transport trajectory and residence time in large river-Lake systems: application to Poyang Lake (China) using a combined model approach. Water 7, 5203-5223. https://doi.org/10.3390/w7105203

Liu, W.-C., Hsu, W.-B., Hsu, M.-H., 2011. Using a three-dimensional particle-tracking model to estimate the residence time and age of water in a tidal estuary. Comput. Geosci. 37, 1148-1161. https://doi.org/10.1016/j.cageo.2010.07.007

Matsumoto, K., Ooe, M., Sato, T. and Segawa, J., 1995. Ocean tide model obtained from TOPEX/POSEIDON altimetry data. Journal of Geophysical Research: Oceans, 100(C12), pp.25319-25330. https://doi.org/10.1029/95JC02777

Patgaonkar, R.S., Vethamony, P., Lokesh, K.S., Babu, M.T., 2012. Residence time of pollutants discharged in the Gulf of Kachchh, northwestern Arabian Sea. Marine Pollution Bulletin. 64:1659-1666. https://doi.org/10.1016/j.marpolbul.2012.05.033

Pham, C.K., et al., 2014. Marine litter distribution and density in European seas, from the shelves to deep basins. PLoS One 9 (4), e95839. https://doi.org/10.1371/journal.pone.0095839
Politikos, D.V., K. Tsiaras, G. Papatheodorou, A. Anastasopoulou. 2019. Modeling of floating marine litter originated from the Eastern Ionian Sea: Transport, residence time and connectivity. Journal of Marine Pollution Bulletin. 1-12. https://doi.org/10.1016/j.marpolbul.2019.110727

Purba, M. dan I. N. Utami. 2006. Karakter Dan Pergerakan Massa Air Di Selat Lombok Bulan Januari 2004 Dan Juni 2005. Jurnal Ilmu-ilmu Perairan dan Perikanan Indonesia, Desember 2006, Jilid 13, Nomor 2: 143-153

Tanaka K, et al. 2013. Accumulation of plastic-derived chemicals in tissues of seabirds ingesting marine plastics. Mar Pollut Bull. 69:219-222. https://doi.org/10.1016/j.marpolbul.2012.12.010

Safak I, Wiberg PL, Richardson DL, Kurum MO. 2015. Controls on residence time and exchange in a system of shallow coastal bays. Continental Shelf Research 97. 7-20. https://doi.org/10.1016/j.csr.2015.01.009

Sala Osvaldo E, Laura A Meyerson, Camille Parmesan. 2009. Biodiversity Change and Human Health: From Ecosystem Services to Spread of Disease. Island Press: 320 pages.

Shen YM, JinHua W, BingHui Z, Hong Z, Yu F, ZaiXing W, and Xu Y. 2011. Modeling study of residence time and water age in Dahuofang Reservoir in China. Science China Physics, Mechanics $\mathcal{E}$ Astronomy. Vol. 54 No. 1. https://doi.org/10.1007/s11433-010-4207-7

Sugiono, 2012. Metode Penelitian Kuantitatif Kualitatif dan RED. Bandung: Alfabeta.

Susanto, R. D., Mitnik, L. and Zheng, Q., 2005. Ocean internal wave observed in the Lombok Strait, Oceanography, Vol.18, pp.80-87

Wang LN. 2014. Analysis of Hydrodynamic Characteristics Based on Random Walk Model in Tonkin Gulf [Master's Thesis]. Xiamen University, Xiamen, China.

Zhang Xueqing, Wang Pengcheng. 2012. Numerical study of residence time in Daliaohe Estuary. International Conference on Computer Distributed Control and Intelligent Enviromental Monitoring. Hal. 451-455 